Aliran Eksistensialisme dalam Pandangan Filsafat Pendidikan Islam

Rabiatul Adawiah

Madrasah dan Transformasi Intelektual Muhdi

Kisah Keluarga Teladan dalam Al-Qur'an (Inspirasi Membangun Negara yang Thayyibah) Rahmat Sholihin

Tasawuf dalam Pandangan Nurcholish Madjid Ilham Masykuri Hamdie dalam Buku The Tao of Islam) Erni Susilawati

Islam, Keindonesiaan, dan Kemanusiaan

(Telaah Pemikiran Ahmad Syafii Maarif) Damanhuri

Pandangan Kritis Islam Liberal atas Isu-Isu Kontemporer Muhammad Taufik 


\section{AL - BANJARI \\ Jurnal Ilmiah Ilmu-Ilmu Keislaman}

Vol. 14, No. 1, Januari-Juni 2015

\section{DAFTAR ISI}

Aliran Eksistensialisme dalam Pandangan Filsafat Pendidikan Islam

Rabiatul Adawiah

Madrasah dan Transformasi Intelektual

Muhdi

Kisah Keluarga Teladan dalam Al-Qur'an (Inspirasi Membangun

Negara yang Thoyyibah)

Rahmat Sholihin

Tasawuf dalam Pandangan Nurcholish Madjid

Ilham Masykuri Hamdie

Psikologi Sufistik (Studi atas Pemikiran Sachiko Murata dalam Buku

The Tao of Islam)

60-75

Erni Susilawati

Islam, Keindonesiaan, dan Kemanusiaan (Telaah Pemikiran

Ahmad Syafii Maarif)

$76-84$

Damanhuri

Pandangan Kritis Islam Liberal atas Isu-Isu Kontemporer

85-105

Muhammad Taufik 


\title{
PANDANGAN KRITIS ISLAM LIBERAL ATAS ISU-ISU KONTEMPORER
}

\author{
Muhammad Taufik \\ Dosen Fakultas Ushuluddin dan Pemikiran Islam UIN Sunan Kalijaga \\ Yogyakarta \\ E-mail: nuraenitaufik@yahoo.com
}

\begin{abstract}
Islam is believed not to be in the contrary of humanity and universal values; justice, virtue and equality. However, it cannot be denied that the reality of current social life of Islam is still marked imbalances. Therefore, it needs serious excavation in rediscovering the spirit of rabmatan lil Alamin as authentic Islam. This paper discusses the views of liberal Islamic groups in relation to the position of women in traditional Islamic societies, especially the issue of polygamy, inheritance rights, women as heads of state, women as imam in the congregational prayers, and the obligation of hijab.
\end{abstract}

Keywords: Islam, liberal Islamic Groups, Humanity and Universal Values,

\section{Pendahuluan}

Ketika pemikiran aktual dan menyerempet masalah pemahaman yang agak sesnsitif tentang ajaran Islam, selalu saja menimbulkan "kegaduhan" yang terkadang menimbulkan masalah yang berkepanjangan. Salahkah hal tersebut? Tentu saja beragam jawaban yang muncul dibenak kita tergantung dari sudut pandang melihatnya. Perbedaan penafsiran dan pemahaman dalam konsep pemikiran, apalagi memasuki ranah isu-isu aktual merupakan hal yang sah-sah saja dan itu bukan hal yang tabu. Apalagi pendekatan yang digunakan ilmiah dan rasional-tektual yang dikemukakan, tentu saja bukan masalah.

Begitulah ketika munculnya pandanganIslam liberal dengan berbagai wacananya hingga saat ini masih menjadi isu 'seksi' dan mudah menimbulkan salah paham di antara kalangan Islam. Muncul dua kubu yang saling berbda satau sama lain, yaitu yang pro dan yang kontra. Bahkan saling mengklaim masing-masing kubunya yag benar dan yang lain salah. Dalam sudut pandang ilmiah biasanya yang dipertanyakan bukan benar salahnya, tapi lebih pada aspek epistemologi atau cara pandang rasional mereka terhadap suatu objek tertentu berdasarkan kerangka keilmuan yang menjadi pisau analisisnya, dan terbuka untuk didiskusikan secara terbuka. Menurut Michel Fucoult hal itu merupakan cara manusia menangkap, memandang, dan memahami kenyataan. ${ }^{1}$ Berbeda dengan sudut pandang normatif-tekstual yang cenderung

1 Eriyanto, Analisis Wacana, (Yogyakarta, LKiS, 2001), hal. 76. 
menjustifikasi dalil sebagai yang paling benar dan beranggapan orang yang di luar kelompoknya adalah salah.

Bertumpu dari pemahaman tersebut tentunya yang menjadi titik tekan sebenarnya adalah bagaimana Islam sebagai agama yang bersifat dinamis menyikapi adanya perbedaan sudut pandang dalam mengkaji dan menganalisis sesuatu, mampu memposisikan Islam sebagai motivasi pemikiran, tindakan serta terkontrol terhadap berbagai fenomena sosial yang menggejala. Walaupun keberadaannya menurut para pemikir Islam adalah statis, dengan anggapan tersebut perlunya adanya paradigma dan gerakan baru untuk membangkitkan Islam dari kungkungan pemikiran yang tidak berkembang secara ilmiah.

Melalui tulisan ini penulis mencoba menyingkap kenapa muncul pandangan yang terkadang minor dalam mengkaji atau memandang Islam liberal? Padahal sesungguhnya banyak pemikiran positif yang muncul dan dapat diambil sebagai pelajaran, bahwa dalam kehidupan manusia tentu saja ada interpretasi dan sudut pandang yang berbeda. Di samping itu banyak kritik-kritik dari Islam liberal yang menurut hemat penulis banyak menjadi support untuk pengembangan Islam ke depannya paling tidak di bidang pengetahuan dan pengamalan ajaran agama.

Posisi penulis tidak mengatakan salah satu benar, tetapi lebih pada upaya penyingkapan dan berdiri pada posisi netral dalam mengemukankan pandangan secara akademik karena keteguhan seseorang dalam mempertahankan argumentasinya akan tercermin apabila produk pemikirannya mampu memberikan dampak perubahan cara pandang terhadap orang lain, seperti yang telah dilakukan oleh para filosof terdahulu, bahwa di antara mereka saling memberikan kontribusi dan pengaruh pemikiran terhadap filosof yang lainnya.Melalui tulisan ini penulis mencoba menyingkap cara pandang Islam liberal terhadap isu-isu kontemporer. Pemakanaan dan interpretasi mereka terkadang menimbulkan ketegangan dan pertentangan di kalangan umat Islam, lebih-lebih dengan kelompok yang anti dengannya. Padahal kalau kita objektif tentu ada hal positifnya, karena Islam liberal berusaha melakukan terobosan pemikiran yang berani dalam menyikapi perkembangan zaman yang penuh dinamika ini,yang terkadang oleh kelompokIslam lainnya seperti kelompok fundamentalis dan puritan dianggap "kebablasan" karena dipersepsikan melewati batas. Misalnya pandangan Islam liberal tentang: otonomi individu untuk menafsirkan al-Quran dan hadis, pandangan yang lebih kritis dan berbagai terhadap teks agama serta pandangan tradisi dalam Islam, kesetaraan gender dalam semua aspek ritual agama, pandangan yang lebih terbuka dalam budaya modern termasuk dalam bidang adat, pakaian dan praktis, dorongan menggunakan ijtihad. Islam liberal dianggap melakukan penafsiran al-Quran yang mereka rasa terlalu konservatif kepada interpretasi yang lebih sedang disuaikan dengan kehidupan modern.

\section{Islam Liberal dan Kemunculannya}

Islam liberal yang terdiri dari dua buah kata, yaitu Islam dan liberal. Islamyang dimaksud adalah agama Islamyang diturunkan oleh Allah kepada Muhammad, sedangkanliberal yang artinya adalah kebebasan. Kata liberal adalah satu istilah asing yang diambil dari kata liberalism dalam bahasa Inggris dan liberalisme dalam bahasa 
perancis yang berarti kebebasan. Kata ini kembali kepada kata liberty dalam bahasa Inggrisnya dan liberte dalam bahasa prancisnya yang bermakna bebas. ${ }^{2}$ Dengan susunan kata tersebut, maka kata liberal berfungsi sebagai keterangan terhadap Islam, sehingga bisa secara bisa dikatakan Islam yang liberal atau bebas.

Banyak pengertian dan definisitentang apa itu Islamliberal, setidaknya untuk kita bisa mendapatkan pengertian yang jelas, beberapa pengamat dan kelompok mendefinisikan apa itu Islam Liberal. Charles Kurzman menyebut enam tolak ukur yang dapat dipakai untuk menyebut pemikiran Islam "Liberal" yaitu: 1). Melawan teokrasi, yaitu ide-ide hendak mendirikan negara Islam, 2). Mendukung gagasan demokrasi, 3). Membela hak-hak perempuan, 4). Membela hak-hak non-muslim, 5). Membela kebebasan berpikir, 6). Membela gagasan kemajuan. Kurzman ingin menunjukkan sekelompok intelektual muslim berusaha mengembangkan gagasan ke-Islaman bersifat toleran, terbuka, dan berkemajuan dalam mengahadapi persoalan global seperti demokrasi, pluralisme, kesetaraan gender, dan modernisasi. ${ }^{3}$

Gerakan Islam liberal, pada dasarnya bertujuan untuk untuk membebaskan (liberating) umat Islam dari belenggu keterbelakangan dan kejumudan.Islam liberal, adalah satu gerakan yang embrionya sudah ada sejak lama. Salah satu gerakan demokratiasi adalah munculnya gerakan-gerakan keagamaan, menandai kesadaran baru dari umat beragama untuk mengambil peran membantu mencarikan alternatif menyelesaikan persoalan-persoalan pada era reformasi. ${ }^{4}$

Bila merujuk pengertian Liberalisme (sebagai aliran) dipahami sebagai paham kebebasan dengan mengedepankan hak individu dalam mengekspresikan segala kondisi dengan bebas, sungguhpun demikian ajaran Islam mengajarkan tentang semangat tenggang rasa, tentu tidak sebatas dalam bentuk kebebasan yang tidak terukur, tetapi sekaligus terkontrol. Apabila kebebasan tanpa melihat kondisi sosial, tentu yang terjadi sebuah kesalahan interprtetasi antara individu dan sosial terhadap persoalan mendasarnya.

Dalam peta dunia dunia Islam telah mengalamai peredebatan-perdebatan di antara tiga interpretasi, sejak lebih abad yang lalu. Pertama, Islam adat, yaitu ditandai dengan kombinasi kebiasaan-kebiasaan kedaerahan dan kebiasaan yang dilakukan oleh hampir seluruh dunia Islam. Semisal di Maroko penghormatan terhadap tokohtokoh yang dianggap suci, di Indonesia menyangkut pertunjukan ritual keagamaan dan kekuatan yang mengekspresikan tradisi budaya daerah. ${ }^{5} \mathrm{Kedua}$, alternatif antara Islam dan adat, kalau meminjam istilah yangdigunakan Fazlur Rahman "Islam Revivalis" atau biasa dikenal dengan fundamentalisme Islam, ${ }^{6}$ dan wahabisme. Tradisi

${ }^{2}$ Hakikat Liberaliyah wa manqif Muslim minha, Sulaiman al-Khirasyi, hal..1 12

3 Anjar Nugroho, Pikiran-Pikiran Liberal Anak Muda Muhammadiyah, (Yogyakarta: SM Press, 2005).

4 Lihat Zuly Qodir, Islam Liberal, Paradigma Baru Wacana dan Aksi Islam Indonesia, (Yogyakarta, Pustaka Pelajar, 2003)

5 Clifford Geertz, Islam Observed Religious Development in Marocco and Indonesia, (Chicago: University of Chicago Press, 1968)

${ }^{6}$ Gellner melihat Islam fundamentalis itu mempunyai sifat kesederhanaan, penuh dengan kekuatan, militansi yang kadang-kadang keras, dan gerakan menjaga masyarakat, mayoritas kehidupannya miskin, mampu mengkondisikan masyarakat dengan kebudayaan kuno yang terkandung dalam 
ini menyerang interpretasi adat yang kurang memberi perhatian pada inti doktrin Islam, mereka menegaskan kepalsuan intitusi-intitusi politik lokal sebagai perebut kedaulatan Tuhan. Gerakan Muhammadbin Abdul Wahab di Arab Saudi adalah sebaagai prototype awal semua gerakan selanjutnya dalam tradisi ini. ${ }^{7}$ Ketiga,Islam liberal, tradisi yang memposisikan dirinya berbeda kontras dengan Islam adat dan mengutamakan priode Islam paling awal untuk menegaskan keabsahan praktekpraktek keagamaan masa kini. Islam liberal menghadirkan kembali masa lalu itu untuk kepentingan modernitas, sebalikya Islam revivalis menegaskan modernitas atasmasa lalu tersebut.Islam liberal melontarkan kritik terhadap Islam adatdan Islam revivalis yang dianggapsebagai keterbelakangan yang dalam sudut padang mereka menghalangi dunnia Islam menikmati modernitas. ${ }^{8}$

Pemikiran liberal Islam mempunyai akar yang jauh sampai di masa keemasan Islam (the golden age of Islam). Teologi rasional Islam yang dikembangkan oleh Mu'tazilah dan para filosof, seperti al-Kindi, al-Farabi, Ibn Sina, Ibn Rusyd dan sebagainya, selalu dianggap telah mampu menjadi perintis perkembangan kebudayaan modern dewasa ini.Pemikiran liberal Islam yang memberi bobot besar terhadap penafsiran baru ajaran Islam dewasa ini, sebenarnya memang mempunyai genealogi pemikiran jauh ke belakang, hingga Ibn Taimiyah (1963-1328) yang menghadapi problem adanya dua sistem pemerintahan, yaitu kekhalifahan yang idealyang pada masanya sudah tidak ada lagidan pemerintahan sekuler yang diperintah oleh sultan Mamluk, saat Ibn Taimiyah juga menjadi pegawainya. Dia juga berhadapan dengan adanya dua sistem hukum, yaitu syari'ah (hukum agama), dan hukum yang diterapkan pemerintahan Mamluk. Menghadapi masalah tersebut, Ibn Taimiyah melakukan refleksi mendalam terhadap keseluruhan tradisi Islam dan situasi baru yang dihadapinya. Dalam keteganganketegangan pilihan ini, Ibn Taimiyah menyarankan suatu "jalan tengah", yaitu suatu sikap moderat. Untuk itu, perlu dilakukan ijtihad (berani berpikir sendiri secara intelektual) pada situasi yang berubah. Suatu ijma' (konsensus) hanya ada dan terjadi pada masa sahabat--oleh karena kesetiaan mreka kepada apa yang dikatakannya dan diperbuatnya, tapi tidak berlaku lagi bagi ahli hukum setelah itu. Dari sudut isi, pemikiran ijtihad Ibn Taimiyah ini sudah merintis suatu metodologi penafsiran teks dan ijtihad atas masalah-masalah sosial-politik, yang kelak menjadi inspirator, terutama kalangan liberalis, juga revivalis dan neo-fundamentalis. Usaha Ibn Taimiyah pun dilanjutkan oleh Ibn Khaldun (1332-1406). Dialah yang merintis sosiologi Islam. Berdasarkan praktek-praktek politik studi historiografinya, Ibn Khaldun--sebagai seorang pengembara dan pengabdi dari banyak kerajaan Islam waktu itu yang terpecahpecah, percaya sepenuhnya kepada pemikiran politik Ibn Taymiyah, terutama tentang

akidahnya, serta menunjukkan sebab-sebab kesengsaraannya itu disebabkan oleh penyimpangan dari jalan yang benar, dan solusi dari semua ini adalah kembali kepada etika dan kekuatan identitas. Lihat, M. Syafi'i Anwar, "Negara dan Cendikiawan Muslim Indonesia Orde Baru", dalam Saiful Muzani, (ed.), Pembangunan dan Kebangkitan Islam di Asia Tenggara, (Jakarta: LP3ES, 1993), hal. 48.

7 Ernest Gelner, Moslem Society, (Cambrige: Cambridge University Press, 1981), hal. 156.

8 Charles Kurzman,Wacana Islam Liberal, Pengantar Islam Dan Konteks Islaminya, (Jakarta, Paramadina, 2003), hal. xvii. 
pentingnya kesejahteraan umum dan hukum ilahiyah demi menjaga kestabilan dan kesejahteraan negara, yang kemudian diperluasnya dengan teori tentang "solidaritas alamiah" dan etika kekuasaan. Sejak Ibn Khaldun ini, pemikiran Islam mengenai sosiologi politik mendapatkan tempat dalam keseluruhan refleksi Islam dan perubahan sosial. Oleh karena itu, penafsiran kembali Islam (ijtihad) menjadi suatu keharusan mutlak dalam masa perubahan politik.Sebenarnya, liberalisme Islam mendapatkan momentum secara politis lebih mendalam pada saat kesultanan Ottoman di Turki, yang oleh segelintir cendekiawan di Konstantinopel dirasakan sebagai ketinggalan zaman, terlalu kaku, dan terlalu religius. Di antara tokoh-tokoh cendekiawan itu adalah Sinasi, Ziya Pasha dan Namik Kemal. Di Mesir, juga ada tokoh-tokoh sekaliber di Turki yang liberal, seperti Rifa' Badawi Rafi' al-Tahtawi (1801-1873), Khayr al-Din Pasha (1810-18819), dan Butrus al-Bustam (1819-1883). Menurut mereka, 'ulama harus dilibatkan dalam pemerintahan, tetapi untuk itu, 'ulama harus terlebih dulu diberikan pendidikan modern yang memadai, agar mereka dapat melihat situasi dan kebutuhan masyarakat modern sekarang ini. Dari para 'ulama itu, dituntut pengetahuan tentang apa itu dunia modern dan problematikanya, supaya tidak terkurung hanya dalam ajaranajaran tradisional. Sementara itu, syari'ah juga harus disesuaikan dengan situasi baru. Antara syari'ah dan hukum alam (ilmu pengetahuan) yang dikembangkan di Eropa dianggap tidak banyak perbedaannya secara prinsipil. Karena itu, pendidikan modern adalah suatu keharusan untuk umat Islam. Juga untuk "memperbaharui" syari'ah itu. ${ }^{9}$

Sebelum Jamaluddin al-Afghani (1839-1897), Muhammad Abduh dan Muhammad Rasyid Ridha (1865-1935), kesadaran bahwa Islam itu--maksudnya tentu saja pemahaman kaum Muslim terhadap Islamharus "dimodernkan" atau "dirasionalkan" sudah menjadi kesadaran umum para cendekiawan Muslim. Dan ini telah menimbulkan gerakan yang oleh Fazlur Rahman disebut sebagai "gerakan modernisme awal." Oleh karena itu pula, Tahtawi dan seluruh kawan-kawannya yang sezaman, telah melihat bahwa Eropa adalah sumber ide dan penemuan yang tak terelakkan. Memang, mereka pun menyadari bahaya yang bisa muncul dari proses "pembaratan" ini. Tetapi, mereka juga yakin bahwa kekuatan gagasan yang progresif dari Barat itu, juga akan mampu mengatasi masalah yang akan muncul. Apalagi, bertepatan dengan munculnya gagasan-gagasan itu, secara politis Ottoman mengalami kemunduran.Selanjutnya, masalah menjadi lain ketika Afghani, 'Abduh dan Rasyd Ridha hidup. Masalah yang dihadapi mereka adalah imperialisme Eropa. Kerajaan Ottoman dalam tahun 1875-1878, telah kemasukan kekuatan militer Eropa. Tahun 1881, Tunisia diduduki Perancis dan tahun 1882, Mesir akhirnya jatuh ke tangan Inggris. Pada tahun-tahun ini pula, semua dunia Islam berada dalam genggaman kolonialisme Eropa, termasuk Indonesia. Sehingga, secara politis keadaan sudah berubah. Maka melihat fenomena Barat-Modern tanpa kritisisme pun menjadi naif. Melalui mereka, muncullah gagasan pan-Islamisme yang mau melawan kolonialisme Barat. Dalam diri mereka, sudah timbul suatu kesadaran bahwa Barat yang modern itu ternyata juga mempunyai sisi destruktif, yakni imperialisme yang menghancurkan kebudayaan Islam baik secara sosial-budaya maupun politis. Timbullah kesadaran 
bahwa yang modern bukan hanya Barat, tetapi bisa juga Islam. Karena itu pemikiran dan gerakan modernisme awal ini, nantinya mendorong munculnya gerakan-gerakan neo-revivalisme, yang terutama dipimpin oleh Hassan al-Banna, Sayyid Qutb, dan Abu 'Al al-Maududi, yang nanti akan "dicap" sebagai akar fundamentalisme Islam kontemporer. ${ }^{10}$

Kemunculan Islam liberal saat menguatnya alirah revivalis pada abad 18 karena adanya upaya-upaya dari kelompok muslim untuk melakukan pembaharauan terhadap Islam yang ada saat itu yang dianggap menyimpang jauh darai ajaran Islam yang disebutkan al-Quran dan hadis. Mereka beranggapan bahwa sudah terjadi banyak terjadi penyimpangan terhadap Islam,sehingga perlu dilakukan upaya pembersihan dan pembaharuan, temasuk di dalamya pengaruh adat tradisi yang ada di dalam suatau bangsa yang mempengaruhi tatacara kebergaamaan mereka.Sebagaimana disebut di atas bahwa gerakan revivalis itu bila di Arab Saudi dilakukan oleh Muhammadbin Abdul Wahab,maka di anak benua India dilakukan oleh syah Waliyullah,walau posisinya menunjukkan dukungan padarevivalis, tetapi ia mengembangkan sebuah pandangan yang lebih humanistik terhadap tradisi atau adat, dibandingkan dengan gerakan yang dilakukan Muhammad bin Abdul Wahab dan pelopor kebngkitan Islam lainnya. Sebab kita tahu apa yang dilakukan oleh Wahabisme di Arab Saudi boleh dibilang agak keras,seperti pembersihan akidah dari hal-hal yang dianggap menyimpang danpenghapusan banyak nilai-nilai situs peninggalan Nabi Muhammad yang dhilangkan dari peta sejarah karena mereka anggap sebagai berhala yang bisa dikultuskan umat Islam.

Dalam kondisi kontra inilah awal abad 20 mucul tokoh muslim yang bisa digolongkan berpikir liberal, seperti Jamaluddin al-Afghani dengan gerakan Pan-Islemamisme dan muridnya Muhammad Abduh di Mesir. ${ }^{11}$ Mereka berdua mendengungkan akan pentingnya suara akal dan ijtihad dari otoritas dan taklid. Sedangkandi India muncul Sayid Ahmad Khan, Sayid Mahdi Ali Khan ${ }^{12}$ yang sangat bersemangat memperjuangkan islam dari keterbelakangan seperti taklid buta. Untuk itu meteode pengajaran dilakukan mengadopsi model Barat yang dalam metode lebih baik dan ditransfer ke wilayah Islam, hal yang sangat ditentang oleh gerakan revivalis atau ataufundamentalis, sebab itu berbau kafir.

\section{Islam Liberal dan Isu-isu global}

Dunia Islam baik di kawasan Timur Tengah, Asia Tenggara, Asia Tengah dan kawasan lainnya di belahan memaknai ajaran Islam dengan ciri lokalitasnya tempat berkembangnya. Sudut pandang, interprertasi danmetodologi unntuk memahami Islam juga berbeda. Begitu juga halnya dengan kelompok-kelompok Islam yang ada, bila meminjam istilah yang digunakan para ahli paling tidak dikelompokkan pada tiga: pertama,kelompok Islam garis keras (Mutasyddid), bisa dikategorikan di dalamnya Islam fudamentalis dan puritan. Kedua, Islammutawassith (Islam moderat), ini bisa disebut

\footnotetext{
${ }^{10} \mathrm{http}: / /$ www.isnet.media.com/nur kholis majid (jurnal pemikiran Universitas Paramadina, Jakarta).

${ }^{11}$ Albert Hourani, Arabic Thought in the Liberal Age (1798-1939), (London: Oxford University Press,1962), hal. 140.

${ }^{12}$ Ibid.
} 
Islam yang berada di tengah. Ketiga,Islammutasahhil atau Islam liberal.

Bila ditelisik model tiga kelompok Islam tersebut, yang cukup menyita perhatian dan ketegangan intelektual sebagaimana penulis singgung di atas adalah kelompok Islam fundamentalis dan Islam liberal, yang kebetulan dua kelompok ini bisa dikatakan saling berhadapan secara head to head satu sama lain karena sudut pandang yang saling bertolak belakang.

Islam liberal pada mulanya diperkenalkan oleh buku "Liberal Islam: A Source Book" yang ditulis oleh Charles Kuzman dan buku "Islamic Liberalis: A Critique of Development Ideologies" yang ditulis oleh Leonard Binder. Walaupun buku ini terbit tahun 1998, tetapi idea yang mendukung liberalisasi telah muncul terlebih dahulu seperti gerakan modernisasi Islam, gerakan sekularisasi dan sebagainya. istilah "Islam Liberal" mulai dipopulerkan sejak tahun 1950-an. Di Timur Tengah, akar-akar gerakan liberalisme Islam bisa ditelusuri hingga awal abad ke-19, ketika apa yang disebut "gerakan kebangkitan" (harakah al-nahdhah) di kawasan itu secara hampir serentak dimulai.Sampai sekarang komunitas Islam Liberal tampak melebarkan sayapnya hingga ke perguruan-perguruan tinggi Islam dengan dukungan akademisi.Istilah Islam Liberal ini dipopulerkan oleh seorang intelektual asal India, Asaf 'Ali Asghar Fyzee, pada tahun 1950-an. Pada salah satu tulisannya dia menuliskan, "Kita tidak perlu menghiraukan nomenklatur'. Tetapi jika sebuah nama harus diberikan padanya, marilah kita sebut itu 'Islam liberal" Kemudian istilah ini dipopulerkan di Indonesia melalui karya Greg barton, Leonard Binder dan Charles Kurzman.

Islam yang merupakan agama pemeluk terbesar kedua di dunia menghadapi berbagai tantangan baik secara internal maupun eksternal. Tantangan itupun tidak terlepas dalam wilayah akidah, muamalah maupun ibadah yang merupakan. Dalam interpretasi wilayah akidah merupakan sesuatu yang agak sensitif bila dilakukan kajian secara rasional-kontekstual. Padahal dinamika perkembangan zaman dengan modernisasi di segala bidang dan tingkat pemahaman seseorang dalam beragama mengalami perkembangan pula. Maka tidak terelakkan muncul pandanganpandanganyang dianggapdiluar dari Islam mainstream oleh kelompok tertentu. Kebetulan pada wilayah itulah Islam liberal yang biasanya berada dalam garda terdepan dalam mengemukakakan pandangan-pandangan kritisnya.

\section{Beberapa Isu-isu Kontemporer}

Sesuai dengan perkembangan zaman berbanding lurus pula perkembangan penafsiran orang terhadap dinamika kehidupannya termasuk dalam bidang agama. Persoalan-persoalan agama dari zaman ke zaman selalu menghadapi perkembangan pula. Semisal isu-isu yang muncul saat ini barang tentu belum ditemukan di masa awal dan pertengahan Islam. Isu-isu kontemporer yang muncul disikapi secara beragam oleh setiap orang. Tidak terhindarkan muncul sikap berseberangan, bertentangan, dan bahkan berakibat saling menjustifikasi satu sama lain. Banyak isu-isu kontemporer yang disikapi kelompok islam tersebut secara beragam.

Paling tidak ada beberapa isuyang cukup hangat dalam kancah pemikiran umat Islam pada umumnya, yaitu demokrasi,Hak Asasi Manusia, pluralisme, dan gender. 


\section{Demokrasi}

Dalam kalangan Islamsendiri memiliki perbedaan dalam mengartikan demokrasi, baik pada tataran konsep, maupun dalam sistem politik yang digunakan dalam menjalankan sebuah roda pemerintahan dan negara pada dasarnya adalah ideal dan baik, begitu pun dengan demokrasi, yang pada tataran idea dan konsepnya merupakan sebuah sistem politik yang dianggap terbaik dari sistem politik yang ada, namun pada tataran praktis para pendukung demokrasi yang hidup di alam demokrasi tersebut terkadang melenceng dari koridor demokrasi yang ada, dengan mengkhianati konsep-konsep demokrasi yang ideal tersebut, yang mesti dikedepankan kemudian adalah komitmen dalam menjalankan sebuah sistem politik, dengan mengikuti koridor-koridor yang ada, apa pun itu sistemnya, termasuk demokrasi. Selain itu dalam Islam sendiri ada yang dengan tegas menolak demokrasi karena dianggap produk buadaya Barat yang sekuuler yang menurut mereka jelas bertentangan dengan nilai-nilai Islam. Mereka ini beranggapan bahwa Islam sebagai agama sangat sempurna dan paripurna dalam konsep hidup bernegara dalam kondisi zaman seperti apapun.

John L. Esposito dan James P. Piscatori memetakan wacana pemikiran politik Islam terhadap demokrasi menjadi tiga aliran; aliran pemikiran Islam yang menolak konsep demokrasi, aliran yang menyetujui prinsip-prinsipnya tetapi mengakui adanya perbedaan, dan aliran yang menerima konsep demokrasi sepenuhnya. ${ }^{13}$ Pertama, bagi kelompok yang menolak demokrasi beranggapan bahwa adalah impossible jika Islam memiliki kesamaan dengan demokrasi. Mereka berpendapat bahwa dalam Islam tidak ada tempat yang layak bagi demokrasi, yang karenanya Islam dan demokrasi tidak dapat dipadukan. Beberapa ulama yang berpandangan demikian antara lain adalah, Syaikh Fadillah Nuri, Thabathabai, dan Sayyid Qutb. Bagi Syaikh Fadillah Nuri, salah seorang ulama Iran, satu kunci gagasan demokrasi yaitu persamaan semua warga negara adalah impossible dalam Islam. Perbedaan luar biasa yang tidak mungkin dihindari pasti terjadi, misalnya, antara yang beriman dan yang tidak beriman, antara kaya dan miskin, dan antara faqib (ahli hukum Islam) dan pengikutnya. Selain itu, ia juga menolak legislasi oleh manusia. Islam katanya, tidak memiliki kekurangan yang memerlukan penyempurnaan. Dalam Islam tidak ada seorangpun yang diizinkan mengatur hukum. Paham konstitusional sebagai bagian dari demokrasi, karenanya bertentangan dengan Islam. dalam keyakinan Syaikh Fadillah Nuri, tampaknya manusia hanya bertugas melaksanakan hukumhukum Tuhan.Sayyid Qutb, Pemikir Ikhwanul Muslimin, sangat menentang gagasan kedaulatan rakyat. Baginya, hal itu adalah pelanggaran terhadap kekuasaan Tuhan dan merupakan suatu bentuk tirani sebagian orang terhadap yang lainnya. Mengakui kekuasaan Tuhan berarti melakukan pertentangan secara menyeluruh terhadap seluruh kekuasaan manusia dalam seluruh pengertian, bentuk, sistem, dan kondisi. Agresi menentang kekuasaan Tuhan di atas bumi merupakan suatu bentuk jahiliyah (kebodohan pra Islam), sambil menekankan bahwa sebuah negara Islam harus berlandaskan pada prinsip musyawarah, ia percaya bahwa syari'ah sebagai

${ }^{13}$ John L. Esposito dan James P. Piscatori, "Islam dan Demokrasi”, dalam Jurnal Islamica, Jurnal Dialog Pemikiran Islam, No. 4 April-Juni 1994, hal. 19-21. 
sebuah sistem hukum dan sistem moral sudah sangat lengkap, sehingga tidak ada legislasi lain yang mengatasinya. Kedua, Kelompok yang menyetujui adanya prinsipprinsip demokrasi dalam Islam tetapi mengakui adanya perbedaan. Kelompok ini diwakili oleh Maududi di Pakistan dan Imam Khomeini dari Iran, serta beberapa pemikir Islam lainnya. Abu 'Ala Maududi misalnya berpandangan bahwa ada kemiripan wawasan antara demokrasi dengan Islam, seperti keadilan, persamaan, akuntabilitas pemerintahan, musyawarah,tujuan negara, dan hak-hak oposisi. Akan tetapi perbedaannya terletak pada kenyataan bahwa dalam sistem Barat, suatu negara demokratis menikmati kedaulatan rakyat mutlak, maka dalam demokrasi Islam, kekhalifahan diterapkan untuk dibatasi oleh batas-batas yang telah digariskan oleh hukum-hukum Ilahi. ${ }^{14}$ Khomeini mempunyai pandangan lain terhadap demokrasi, menurutnya demokrasi Islam berbeda dengan demokrasi liberal, ia meyakini bahwa kebebasan mesti dibatasi dengan hukum, dan kebebasan yang diberikan itu harus dilaksanakan di dalam batas-batas hukum Islam dan konstitusi, dengan sebaik-baiknya. ${ }^{15}$ Konstitusi Republik Islam Iran yang didasarkan pada konsep wilayatul faqib mencerminkan bahwa di satu sisi Iran merupakan negara Islam yang bersumber pada hukum agama, namun di sisi lain Iran termasuk merupakan sebuah negara yang secara prinsipil menganut sistem demokrasi.Ketiga, kelompok yang menerima sepenuhnya konsep demokrasi memandang bahwa sejatinya di dalam diri Islam sangat demokratis karenanya menurut mereka Islam menerima sepenuhnya demokrasi sebagai sesuatu yang universal. Pemikir yang masuk dalam kategori kelompok ketiga ini antara lain, Muhammad Husain Haikal dari Mesir, Rashid al-Ghannouchi, pemikir politik asal Tunisia, serta Bani Sadr dan Mehdi Bazargan dari Iran.

Muhammad Husein Haikal, salah seorang pemikir muslim dari Mesir, berpendapat bahwa dalam dunia pemikiran, demokrasi pertama kali dicanangkan oleh Islam, menurutnya, semua sistem yang tidak berdiri di atas prinsip-prinsip demokrasi adalah tidak sesuai dengan kaidah-kaidah utama yang ditetapkan dan diserukan Islam. Karena, kaidah-kaidah yang ditetapkan demokrasi merupakan kaidah Islam dan begitu pula dengan prinsip-prinsipnya. Islam dan demokrasi samasama berorientasi kepada fitrah manusia. Haikal mendasarkan pikirannya kepada prinsip musyawarah, prinsip persaudaraan Islam, prinsip persamaan, prinsip ijtihad (penalaran pribadi) atau kebebasan berpikir terutama dalam masalah yang tidak ada kaitannya dengan syariah. prinsip legislasi yang wewenangnya hanya dimiliki oleh para hakim dan tidak dimiliki oleh khalifah atau imam, prinsip ijma' (kesepakatan para ahli), pengawasan terhadap penguasa, akuntabilitas serta pengendalian nafsu bagi penguasa. Semua itu merupakan prinsip-prinsip dari sistem politik yang dipraktekkan Nabi di Madinah.

Islam adalah agama yang sangat terbuka dan akomodatif terhadap segala perkembangan kebudayaan manusia dengan konsep-konsep yang dikembangkannya.

${ }^{14}$ Sukron Kamil, Islam dan Demokrasi: Telaah Konseptual dan Historis (Jakarta: Gaya Media Pratama, 2002), hlm 47-48 ; Ira M. Lapidus, Sejarah Sosial Umat Islam, Bagian 3, terj. Ghufron A. Mas'adi (Jakarta: Raja Grafindo Persada, 1999), hal. 38-49.

${ }^{15}$ Yamani, Antara Al-Farabi dan Khomeini: Filsafat Politik Islam (Bandung: Mizan), 2002, Cet. I, hal. 141. 
Demokrasi, bagi Islam, bukanlah sesuatu yang asing karena di dalamnya terkandung konsep kesetaraan diantara seluruh manusia. Islam sebenamya tidak pemah memandang demokrasi sebagai kebudayaan Barat yang harus dihindari. Memang konsep itu secara kultural berkembang di Barat tetapi secara internal telah ada dalam Islam. Tidak suatu bukti yang jelas dan transparan yang dapat dijadikan indikator bahwa konsep demokrasi menyalahi dan bertentangan dengan syura Demokrasi memang menimbulkan banyak pertanyaan rilosons untuk menentukan batasan-batasannya. Kerumitan titik pijak diskusi demokrasi ini memberi kesan bahwa demokrasi memang tidak dapat diidentikkan dengan atribut-atribut tertentu. Dalam hal ini, demokrasi memang kiranya tidak perlu diidentikkan dengan demokrasi liberal Barat (walaupun dalam banyak kesempatan diklaim bahwa peradaban yang mutakhir dewasa ini adalah demokrasi lib- eral Barat). Kembali ke awal tulisan ini, sebagai prinsip dasar cukuplah diandaikan bahwa demokrasi adalah perimbangan politik dalam kehidupan bermasyarakat dan bernegara.

2. Hak Asasi Manusia

Hak asasi manusia atau biasa disingkat HAM merupakan sebuah hal yang menjadi keharusan dari sebuah negara untuk menjaminnya dalam konstitusinya. Melalui deklarasi universal ham 10 desember 1948 merupakan tonggak bersejarah berlakunya penjaminan hak mengenai manusia sebagai manusia. Sejarah HAM dimulai dari magna charta di inggris pada tahun 1252 yang kemudian kemudian berlanjut pada bill of rights dan kemudian berpangkal pada DUHAM PBB.

Tonggak berlakunya HAM internasional ialah pada Deklarasi Universal Hak Asasi Manusia (DUHAM) pada 10 Desember 1948 di Paris, Prancis. Disini tonggak deklarasi universal mengenai hak asasi manusia yang mengakui hak setiap orang diseluruh dunia. Deklarasi ini ditanda tangani oleh 48 negara dari 58 negara anggota PBB dan disetujui oleh majelis umum PBB. Perumusan penghormatan dan pengakuan norma-norma HAM yang bersifat universal, nondiskriminasi, dan imparsial telah berlangsung dalam sebuah proses yang sangat panjang. Sejarah awal hak asasi manusia di barat berkembang sejak tahun 1215 yaitu dalam Magna Charta yang berisi aturan mengenai tindakan dan kebijakan negara supaya tidak berjalan sewenang-wenang. Isi dari Magna Charta ialah bermaksud untuk mengurangi kekuasan penguasa. Usaha untuk diadakannya Magna Charta ini dimulai dari perjuangan tuan tanah dan gereja untuk membatasi kekuasaan raja dan para anggota keluarga. Pada periode awal ini hubungan antara isi dasar HAM adalah mengenai (hubungan) antara anggota masyarakat yang berada dibawaha kekuasaan yang diatur kebendaanya. Ada tiga prinsip utama dalam pandangan normatif hak asasi manusia, yaitu berlaku secara universal, bersifat non-diskriminasi dan imparsial. Prinsip keuniversalan ini dimaksudkan agar gagasan dan norma-norma HAM telah diakui dan diharapkan dapat diberlakukan secara universal atau internasional. Prinsip ini didasarkan atas keyakinan bahwa umat manusia berada dimana-mana,disetiap bagian dunia baik di pusat-pusat kota maupun di pelosok pelosok bumi yang terpencil. Berdasar hal itu ham tidak bisa didasarkan secara partikular yang hanya diakui kedaerahahan dan diakui secara local.Prinsip kedua dalam norma HAM adalah sifatnya yang non-diskriminasi. 
Prinsip ini bersumber dari pandangan bahwa semua manusia setara (all human being are equal). Pandangan ini dipetik dari salah satu semboyan Revolusi Prancis, yakni persamaan (egalite). Setiap orang harus diperlakukan setara. Seseorang tidak boleh dibeda-bedakan antara satu dengan yang lainnya. Akan tetapi latar belakang kebudayaan sosial dan tradisi setiap manusia diwilayahnya berbedabeda. Hal ini tidak bisa dipandang sebagai suatu hal yang negatif, melainkan harus dipandang sebagai kekayaan umat manusia. Karena manusia berasal dari keanekaragaman warna kulit seperti kulit putih,hitam, kuning dan lainnya. Keanekaragam kebangsaan dan suku bangsa atau etnisitas. Kenekaragaman agama juga merupakan sesuatu hal yang mendapat tempat dalam sifat non-diskriminasi ini. Pembatasan sesorang dalam beragama merupakan sebuah pelanggaran HAM. Prinsip ketiga ialah imparsialitas. Maksud dari prinsip ini penyelesaian sengketa tidak memihak pada suatu pihak atau golongan tertentu dalam masyarakat. Umat manusia mempunyai beragam latar belakang sosial aupun latar belakang kultur yang berbeda antara satu dengan yang lain hal ini meupakan sebuah keniscayaan. Prinsip imparsial ini diimaksudkan agar hukum tidak memihak pada suatu golongan. Prinsip ini juga dimaksudkan agar pengadilan sebuah kasus diselesaikan secara adil atau tidak meihak pada salah satu pihak. Pemihakan hanyalah pada norma-norma ham itu sendiri.

Setiap manusia harus mengerti terlebih dahulu hak-hak dasar yang melekat pada dirinya seperti kebebasan, persamaan, perlindungan dan sebagainya. Hak-hak tersebut bukan merupakan pembererian seseorang, organisasi, atau Negara, tapi adalah anugrah Allah yang sudan dibawanya sejak lahir kea lam dunia. Hak-hak itulah yang kemudian disebut dengan Hak Azazi Mannusia. Tanpa memahami hak-hak tersebut adalah mustahil ia dapat menjalankan tugas serta kewajibannya sebagai khalifah Tuhan. Namun persoalannya kemudian, apakah setiap manusia dan setiap muslim sudah menyadari hak-hak tersebut? Jwabannya, mungkin belum setiap orang, termasuk umat Islam menyadarinya. Hal ini mungkin akibat rendahnya pendidikan atau sistem social politik dan budaya di suatu tempat yang tidak kondusif untuk anak dapat bekembang dengan sempurna. ${ }^{16}$

Pada dasarnya HAM dalam Islam terpusat pada lima hal pokok yang terangkum dalam al-dloruriyat al-khomsah atau yang disebut juga al-huquq al-insaniyah fi al-Islam (hak-hak asasi manusia dalam Islam). Konsep ini mengandung lima hal pokok yang harus dijaga oleh setiap individu, yaitu hifdzu al-din (penghormatan atas kebebasan beragama), hifdzu al-mal (penghormatan atas harta benda), hifdzu al-nafs wa al-'ird (penghormatan atas jiwa, hak hidup dan kehormatan individu) hifdzu al-'aql(penghormatan atas kebebasan berpikir) dan hifdzu al-nasl(keharusan untuk menjaga keturunan). Kelima hal pokok inilah yang harus dijaga oleh setiap umat Islam supaya menghasilkan tatanan kehidupan yang lebih manusiawi, berdasarkan atas penghormatan individu atas individu, individu dengan masyarakat, masyarakat dengan masyarakat, masyarakat dengan negara dan komunitas agama dengan komunitas agama lainnya

\footnotetext{
${ }^{16}$ Kosasih, Ahmad. HAM Dalam Perspektif Islam, (Jakarta:Salemba Diniyah, 2003), Hal. 5.
} 
Dalam Islam, konsep mengenai HAM sebenarnya telah mempunyai tempat tersendiri dalam pemikiran Islam. Perkembangan wacana demokrasi dengan Islam sebenarnya yang telah mendorong adanya wacana HAM dalam Islam. Karena dalam demokrasi, pengakuan terhadap hak asasi manusia mendapat tempat yang spesial. Berbagai macam pemikiran tentang demokrasi dapat dengan mudah kita temukan didalamnya konsep tentang penegakan HAM.

HAM menurut Islam berprinsip menjunjung tinggi martabat manusia. Di samping itu HAM menurut Islam juga menghendaki adanya persamaan, kebebasan menyatakan pendapat, kebebasan beragam, dan jaminan sosial. Prinsip kebebasan menyatakan pendapat adalah kebebasan yang dibimbing ajaran Allah, yaitu alQur'an menurut sunnah rasul. Manusia bebas berbicara dan berprilaku sesuai dengan ajaran Allah. Kebebasan menyatakan pendapat merupakan perwujudan dari instruksi Allah. Prinsip hak atas jaminan sosial dalam prinsip ini ditegaskan bahwa pada harta orang kaya terdapat hak fakir miskin. Oleh karena itu, orang Islam diharuskan membayar zakat.

3. Pluralisme

Pluralisme berasal dari bahasa Inggris "plural” yang berarti jamak atau banyak, adapun pluralisme itu sendiri berarti suatu paham atau teori yang menganggap bahwa realitas itu terdiri dari banyak substansi. ${ }^{17}$ Pluralisme biasa dipakai untuk melihat makna realitas keragaman sosial-masyarakat sekaligus sebagai prinsip atau sikap terhadap keragaman itu, kemajemukan dalam unsur budaya maupun keragaman manusia dengan segala aspeknya.Allah telah menciptakan manusia dengan berbagai macam keunikan mulai dari: warna kulit, jenis kelamin, bahasa, suku, dan postur tubuh serta keragaman agama dan budaya yang berbeda dari manusia satu dengan lainnya. Kemajemukan memang murni kekuasaan Allah SW'T bukan berarti Ia tidak mampu menciptakan ummat yang satu. Kenapa Allah tidak menghendaki demikian? Karena dengan ini manusia akan diuji kesalehannya, untuk dapat menghormati dan menghargai antar person ciptaan-Nya dan berlomba-lomba dalam hal kebaikan. Kalau memang keragaman merupakan sunatullah maka tidak ada sikap lain bagi muslim terhadap pluralitas itu kecuali menerima sepenuhnya. Pluralisme adalah suatu keharusan bagi keselamat umat manusia di muka bumi dan merupakan wujud kemurahan Allah yang melimpah kepada manusia. Allah menciptkan umat yang majemuk karena di situ terletak kekuatan penyeimbang dan mekanisme pengawasan antara sesama manusia.

penghormatan atas pluralitas adalah suatu keharusan. Secara tegas Islam menolak dan melarang manusia merendahkan golongan lain dan menganjurkan untuk bersifat khusnudzan (berbaik sangka), dengan kata lain umat satu dapat melihat secara obyektif kelemahan diri sendiri dan dapat mengambil pelajaran positif dari orang lain.

Selain manusia diharuskan untuk menghormati dan mengenal kelompok manusia yang berbeda agama, ada sisi penting yang seyogyanya terus dilakukan oleh umat manusia yaitu untuk melakukan musyawarah dan kerjasama guna

${ }^{17}$ Pius A. Partanto dan M. Dahlan Al Barry, Kamus Ilmiah Populer (Surabaya: Ar Kolah, 1994), hal. 604 
membangun peradaban di muka bumi ini. Penghormatan atas kemajemukan telah dicontohkan oleh Rasulullah dalam usahanya melakukan konsolidasi dengan masyarakat madinah yang kemudian disebut: perjanjian madinah atau piagam madinahDengan demikian pluralitas masyarakat baik mengenai sifat manusia maupun kemajemukan budaya sama sekali tidak bertentangan dengan ajaran Islam tidak terkecuali pluralitas masyarkat Indonesia. Kemajemukan suatu masyarakat atau bangsa haruslah tetap dipelihara dan dijaga bersama demi tegaknya keadilan dan keamanan hidup manusia yang berbangsa dan bernegara.

Proses reduksi ini akan terus-menerus terjadi dari generasi ke generasi. Oleh karena itu perlu diketahui bahwa ajaran Islam yang sesungguhnya adalah ajaran yang belum mengalami reduksi (Islam yang ideal: hanya diketahui dan dikehendaki Allah). Ini yang harus ditangkap oleh umat Islam. Berbagai tafsir al-Qur'an dan Imam Madzab ditulis dalam rangka memahami kesempurnaan ajaran Islam tersebut. Kesempurnaan ajaran Allah tentu tidak dapat seluruhnya ditangkap oleh manusia karena pada hakikatnya kesempurnaan milik Allah. Di sinilah letak esensi dari keberagamaan dan keragaman umat yakni ada pencarian terus-menerus (on going quest), dan proses menjadi tanpa batas (timeless process of becoming). Pemahaman dan penafsiran yang berbeda harus disikapi dengan rasa penghormatan dan dihargai sebagai rahmat Allah.Merespon pluralisme dalam kehidupan bermasyarkat. H. A. Mukti Ali lebih cenderung berpedoman pada cara agree in disagreement (setuju dalam perbedaan), dalam cara pandang ini seseorang berasumsi dan percaya agama yang dipeluk adalah agama yang paling baik dan benar di antara yang lainnya, selain terdapat perbedaan juga ada persamaan. ${ }^{18}$ Berbeda dengan Amin Abdullah bahwa sikap agree in disagreement tidak cocok untuk level kehidupan sosial, karena konsep ini masih tampak menonjolkan pendekatan teologi dan kalam, lantaran disagreementnya masih sempat ditonjolkan, sedang agreenya bisa saja sempat tertindih oleh disagreement. ${ }^{19}$ Dan ia lebih cocok dengan pola kontrak sosial dalam menyikapi pluralitas masyarakat, hal ini dikarenakan bahwa manusia harus menjalin hubungan kerjasama dengan manusia lain dalam membangun dan memecahkan masalah bersama. Dengan demikian dalam kontak sosial ada kecenderungan menerima dengan tulus atas perbedaan itu dibaregi dengan dialog untuk mengambil nilai lebih. Bukan berarti untuk menafikkan hakikat kebenaran yang diyakini.

4. Gender

Gender adalah seperangkat peran yang seperti halnya kostum dan topeng di teater menyampaikan kepada orang lain bahwa kita adalah feminine atau maskulin. Perangkat perilaku khusus ini yang mencakup penampilan, pakaian, sikap, kepribadian, bekerja di dalam dan di luar rumah tangga, seksualitas, tanggung jawab keluarga dan sebagainya secara bersama-sama memoles peran gender kita. ${ }^{20}$

\footnotetext{
${ }^{18}$ M. Jandra, "Pluralisme Baru dan Cinta Kebangsaan", Amin Abdullah, dkk, Tafsir Baru Studi Islam dalam Era Multi Kultural (Yogyakarta: Kurnia Kalam Semesta, 2002), hal. 255.

${ }^{19} \mathrm{Ibid}$

${ }^{20}$ Julia Cleves Mosse, Gender \& Pembangunan, (Yogyakarta: Pustaka Pelajar, 1996), hal. 3.
} 
Dalam pandangan hukum Islam, segala sesuatu diciptakan Allah dengan kodrat. Demikian halnya manusia, antara laki-laki dan perempuan sebagai individu dan jenis kelamin memiliki kodratnya masing-masing. Al-Qur'an mengakui adanya perbedaan anatomi antara laki-laki dan perempuan. Al-Qur'an juga mengakui bahwa anggota masing-masing gender berfungsi dengan cara merefleksikan perbedaan yang telah dirumuskan dengan baik serta dipertahankan oleh budaya, baik dari kalangan kaum laki-laki maupun perempuan sendiri.

Kodrat perempuan sering dijadikan alasan untuk mereduksi berbagai peran perempuan di dalam keluarga maupun masyarakat, kaum laki-laki sering dianggap lebih dominan dalam memainkan berbagai peran, sementara perempuan memperoleh peran yang terbatas di sektor domestik. Kebudayaan yang berkembang dalam masyarakat pun memandang bahwa perempuan sebagai makhluk yang lemah, emosional, halus dan pemalu sementara laki-laki makhluk yang kuat, rasional, kasar serta pemberani. Anehnya perbedaan-perbedaan ini kemudian diyakini sebagai kodrat, sudah tetap yang merupakan pemberian Tuhan. Barang siapa berusaha merubahnya dianggap menyalahi kodrat bahkan menentang ketetapan Tuhan.

Al-Qur'an tidak mengajarkan diskriminasi antara lelaki dan perempuan sebagai manusia. Di hadapan Tuhan, lelaki dan perempuan mempunyai derajat yang sama, namun masalahnya terletak pada implementasi atau operasionalisasi ajaran tersebut. Kemunculan agama pada dasarnya merupakan jeda yang secara periodik berusaha mencairkan kekentalan budaya patriarkhi. Oleh sebab itu, kemunculan setiap agama selalu mendapatkan perlawanan dari mereka yang diuntungkan oleh budaya patriarkhi. Sikap perlawanan tersebut mengalami pasang surut dalam perkembangan sejarah manusia.

Untuk memahami konsep gender harus dibedakan kata gender dengan kata seks (jenis kelamin). Pengertian jenis kelamin merupakan pensifatan atau pembagian dua jenis kelamin manusia yang ditentukan secara biologis yang melekat pada jenis kelamin tertentu. Sedangkan konsep lainnya adalah konsep gender yakni suatu sifat yang melekat pada kaum laki-laki maupun perempuan yang konstruksi secara sosial maupun cultural. ${ }^{21}$

Kesetaraan yang telah di akui oleh Al Qur'an tersebut, bukan berarti harus sama antara laki- laki dan perempuan dalam segala hal.Untuk menjaga kesimbangan alam (sunnatu tadafu'), harus ada sesuatu yang berbeda, yang masing-masing mempunyai fungsi dan tugas tersendiri. Tanpa itu, dunia, bahkan alam ini akan berhenti dan hancur. Oleh karenanya, sebgai hikmah dari Allah untuk menciptakan dua pasang manusia yang berbeda, bukan hanya pada bentuk dan postur tubuh serta jenis kelaminnya saja, akan tetapi juga pada emosional dan komposisi kimia dalam tubuh.

Hal ini akibat membawa efek kepada perbedaan dalam tugas, kewajiban dan hak. Dan hal ini sangatlah wajar dan sangat logis. Ini bukan sesuatu yang di dramatisir sehingga merendahkan wanita, sebagaimana anggapan kalangan feminis dan ilmuan Marxis. Tetapi merupakan bentuk sebuah keseimbangan hidup dan kehidupan,

\footnotetext{
${ }^{21}$ Mansour Fakih, Analisi Gender \& Transformasi Sosial, (Yogyakarta: Pustaka Pelajar, 1996), hal. 8
} 
sebagiamana anggota tubuh manusia yang berbeda- beda tapi menuju kepada persatuan dan saling melengkapi. Oleh karenanya, suatu yang sangat kurang bijak, kalau ada beberapa kelompok yang ingin memperjuangkan kesetaraan antara dua jenis manusia ini dalam semua bidang. Al Qur'an telah meletakkan batas yang jelas dan tegas di dalam masalah ini, salah satunya adalah ayat- ayat yang terdapatdi dalam surat al Nisa. Terutama yang menyinggung konsep pernikahan poligami, hak waris dan dalam menentukan tanggungjawab di dalam masyarakat dan keluarga. Ulama kontemporer ternama Yusuf Al-Qordhawi memiliki pandangan dan pendapat yang berbeda terhadap kepemimpinan wanita dalam berpolitik. Beliau menjelaskankan bahwa penafsiran terhadap surat an-nisa ayat 34 bahwa laki-laki adalah pemimpin bagi wanita dalam lingkup keluarga atau rumah tangga. Jika ditinjau tafsir surat An-Nisa ayat 34 bahwa laki-laki adalah pemimpin wanita, bertindak sebagai orang dewasa terhadapnya, yang menguasainya, dan pendidiknya tatkala dia melakukan penyimpangan. "Karena Allah telah mengunggulkan sebagian mereka atas sebagian yang lain. Yakni, karena kaum laki-laki itu lebih unggul dan lebih baik daripada wanita. Oleh karena itu kenabian hanya diberikan kepada kaum laki-laki.

Laki-laki menjadi pemimpin wanita yang dimaksud ayat ini adalah kepemimpinan dirumah tangga, karena laki-laki telah menginfakkan hartanya, berupa mahar, belanja dan tugas yang dibebankan Allah kepadanya untuk mengurus mereka. Tafsir ibnu katsir ini menjelaskan bahwa wanita tidak dilarang dalam kepemimpinan politik, yang dilarang adalah kepemimpinan wanita dalam puncak tertinggi atau top leader tunggal yang mengambil keputusan tanpa bermusyawarah, dan juga wanita dilarang menjadi hakim. Hal inilah yang mendasari Qardhawi memperbolehkan wanita berpolitik.

Quraish Shihab juga menambahkan bahwa dalam Al-Qur'an banyak menceritakan persamaan kedudukan wanita dan pria, yang membedakannya adalah ketaqwaanya kepada Allah. Tidak ada yang membedakan berdasarkan jenis kelamin, ras, warna kulit dan suku. Kedudukan wanita dan pria adalah sama dan diminta untuk saling bekerjasama untuk mengisi kekurangan satu dengan yang lainnya, sebagai mana di jelaskan dalam surat At-Taubah ayat 71 yang berbunyi:

Artinya: "Dan orang-orang yang beriman, lelaki dan perempuan, sebahagian mereka (adalah) menjadi penolong bagi sebahagian yang lain. mereka menyuruh (mengerjakan) yang ma'ruf, mencegah dari yang munkar, mendirikan shalat, menunaikan zakat dan mereka taat pada Allah dan Rasul-Nya. mereka itu akan diberi rahmat oleh Allah; Sesungguhnya Allah Maha Perkasa lagi Maha Bijaksana." Islam sebenarnya tidak menempatkan wanita berada didapur terus menerus, namun jika ini dilakukan maka ini adalah sesuatu yang baik, hal ini di nyatakan oleh imam Al-Ghazali bahwa pada dasarnya istri tidak berkewajiban melayani suami dalam hal memasak, mengurus rumah, menyapu, menjahid, dan sebagainya. Akan tetapi jika itu dilakukan oleh istri maka itu merupakan hal yang baik. Sebenarnya suamilah yang berkewajiban untuk memberinya/menyiapkan pakaian yang telah dijahid dengan sempurna, makanan yang telah dimasak secara sempurna. Artinya kedudukan wanita dan pria adalah saling mengisi satu dengan yang lain, tidak ada 
yang superior. Hanya saja laki-laki bertanggung jawab untuk mendidik istri menjadi lebih baik di hadapan Allah SWT.

Sebenarnya hanyalah permainan kaum feminis saja yang menyatakan bahwa lakilaki superior dibandingkan dengan wanita, agar mereka dapat melakukan hal-hal yang melampaui batas, dengan dalih bahwa wanita dapat hidup tanpa laki-laki, termasuk dalam hal seks, sehingga muncullah fenomena lesbian percintaan sesama jenis, banyaknya fenomena kawin cerai karena sang istri menjadi durhaka terhadap suami, padahal dalam rumah tangga pemimpin keluarga adalah laki-laki, sedangkan dalam hal berpolitik tidak ada larangan dalam Islam untuk berpolitik dan berkarier. Qardhawi dalam hal ini kembali mempertegas bahwa kepemimpinan kepala negara dimasa sekarang ini kekuasaannya tidak sama dengan seorang ratu atau khalifah di sama lalu yang identik dengan seorang imam dalam shalat. Sehingga kedudukan wanita dan pria dalam hal perpolitikan adalah sejajar karena sama-sama memiliki hak memilih dan hak dipilih. Dengan alasan bahwa wanita dewasa adalah manusia mukallaf (diberi tanggung jawab) secara utuh, yang dituntut untuk beribadah kepada Allah, menegakan agama, dan berdakwah ${ }^{22}$.

Menurut Abu Hanifah seorang perempuan dibolehkan menjadi hakim, tetapi tidak boleh menjadi hakim dalam perkara pidana. Sementara Imam Ath-Thabari dan aliran Dhahiriyah membolehkan seseorang perempuan menjadi hakim dalam semua perkara, sebagaimana mereka membolehkan kaum perempuan untuk menduduki semua jabatan selain puncak kepemimpinan negara. ${ }^{\left[{ }^{[6]}\right.}$

Dalam pandangan Islam perempuan memiliki kedudukan yang sama dibandingkan dengan laki-laki. Dari sudut penciptaan, kemuliaan, dan hak mendapatkan balasan atas amal usahanya perempuan memiliki kesetaraan dengan laki-laki. Sedangkan dalam hal peran perempuan memiliki perbedaan dengan laki-laki. Peran perempuan yang wajib adalah sebagai anggota keluarga yaitu sebagai istri dari suami dan ibu bagi anak-anaknya. Sedangkan peran perempuan sebagai anggota masyarakat dalam urusan muamalah mendapatkan profesi (pekerjaan) dihukumi dengan rukhshah darurat. Meskipun diperbolehkan namun harus selalu mementingkan segi kemaslahatan baik bagi rumah tangga maupun bagi masyarakat. Apabila lebih banyak kemudaratannya bagi keluarga maka profesi di luar rumah harus ditinggalkan mengingat sesuatu yang darurat tidak boleh meninggalkan hal yang wajib.

Pada dasarnya gerakan gender merupakan upaya mencari keadilan, ingin menempatkan perempuan pada posisi yang proporsional, sama, dan setara dengan laki-laki sehingga tidak ada perbedaan-perbedaan yang bersifat diskriminatif ${ }^{23}$

Untuk lebih jelasnya, perpedaan antara seks (jenis kelamin) dan gender dapat dilihat dalam tabel berikut ini:

\footnotetext{
${ }^{22}$ Leila Ahmed, Wanita \& Gender Dalam Islam, (Jakarta: PT. Lentera Basritama, 2000), hal. 87

${ }^{23}$ Zahara D. Noer, "Kemitrasejajaran Pria dan Wanita dalam Perspektif Islam", dalam Tuntunan Islam tentang Kemitrasejajaran Pria dan Wanita, (Jakarta: Majlis Ulama Indonesia, 1999), hal. 43.
} 
Perbedaan Laki-Laki dan Perempuan Berdasarkan Seks

\begin{tabular}{|c|c|c|}
\hline KATEGORI & PEREMPUAN & LAKI-LAKI \\
\hline Alat kelamin & $\begin{array}{c}\text { Vagina, memiliki rahim, dan } \\
\text { payudara }\end{array}$ & Penis dan sperma \\
\hline Potensi & $\begin{array}{c}\text { Menstruasi, hamil, melahirkan, dan } \\
\text { menghasilkan ASI }\end{array}$ & Pembuahan \\
\hline
\end{tabular}

Perbedaan Laki-Laki dan Perempuan Berdasarkan Gender

\begin{tabular}{|c|c|c|}
\hline KATEGORI & PEREMPUAN & LAKI-LAKI \\
\hline Sifat & Feminim & Maskulin \\
\hline Lingkup Kegiatan & Domestik & Publik \\
\hline Fungsi & Reproduktif & Produktif \\
\hline Peran & $\begin{array}{c}\text { Pencari nafkah tambahan } \\
\text { Ibu rumah tangga }\end{array}$ & $\begin{array}{c}\text { Pencari nafkah utama } \\
\text { Kepala keluarga }\end{array}$ \\
\hline
\end{tabular}

Kesetaraan gender berarti kesamaan kondisi bagi laki-laki dan perempuan untuk memperoleh kesempatan serta hak-haknya sebagai manusia, agar mampu berperan dan berpartisipasi dalam kegiatan politik, hukum, ekonomi, sosial budaya, pendidikan, dan pertahanan dan keamanan nasional (hankamnas), serta kesamaan dalam menikmati hasil pembangunan tersebut. Kesetaraan gender juga meliputi penghapusan diskriminasi dan ketidak adilan struktural, baik terhadap laki-laki maupun perempuan.

Keadilan gender adalah suatu proses dan perlakuan adil terhadap perempuan dan laki-laki. Dengan keadilan gender berarti tidak ada pembakuan peran, beban ganda, subordinasi, marginalisasi dan kekerasan terhadap perempuan maupun laki-laki.

Terwujudnya kesetaran dan keadilan gender ditandai dengan tidak adanya diskriminasi antara perempuan dan laki-laki, dan dengan demikian mereka memiliki akses, kesempatan berpartisipasi, dan kontrol atas pembangunan serta memperoleh manfaat yang setara dan adil dari pembangunan. Memiliki akses dan partisipasi berarti memiliki peluang atau kesempatan untuk menggunakan sumber daya dan memiliki wewenang untuk mengambil keputusan terhadap cara penggunaan dan hasil sumber daya tersebut. Memiliki kontrol berarti memiliki kewenangan penuh untuk mengambil keputusan atas penggunaan dan hasil sumber daya. Sehingga memperoleh manfaat yang sama dari pembangunan.

Ketimpangan sosial-budaya antara laki-laki dan perempuan masih sering dipertahankan dengan dalili-dalil agama. Bahasa agama-agama, terutama agama-agama anak cucu Nabi Ibrahim (Abrahamic Religions), secara tekstual memang banyak memihak 
kepada laki-laki. Tuhan digambarkan sebagai sosok laki-laki, sebagaimana terlihat pada kata ganti Tuhan dengan menggunakan kata ganti laki-laki هو. Bahkan beberapa agama tertentu mengidialisir sosok laki-laki sebagai setengah Tuhan dan perempuan sebagai setengah iblis. Bahasa-bahasa agama seringkali dilibatkan untuk melestarikan kondisi di mana kaum perempuan tidak menganggap dirinya sejajar dengan laki-laki ${ }^{24}$

Isu ketidak setaraan antara laki-laki dan perempuan, memunculkan gerakan untuk memperjuangkan hak-hak perempuan. Hal ini juga dilakukan oleh kaum feminisme, yaitu gerakan yang sudah tua, namun baru pada tahun 60-an dianggap sebagai lahirnya gerakan itu. Gerakan feminisme itu muncul di Amerika sebagai bagian dari kultur radikal hak-hak sipil (civil rights) dan kebebasan seksual (sexual liberation). Buku Betty Friedan yang berjudul The Feminist Mystique (1963) laku keras. Setelah itu berkembang kelompok feminis yang memperjuangkan nasib kaum perempuan memenuhi kebutuhan praktis, seperti pengasuhan anak (cbildcare), kesehatan, pendidikan, aborsi, dan sebagainya. Kemudian, gerakan itu merambat ke Eropa, Kanada, dan Australia yang selanjutnya kini telah menjadi gerakan global dan mengguncang Dunia Ketiga.

Berbeda dengan pandangan para feminis, Islam diturunkan oleh Allah Yang Maha Adil dan Maha Mengetahui hakikat kaum Hawa, maka kaum perempuan ditempatkan pada posisi yang layak demi kepentingan dan kebahagiaan mereka di dunia maupun di akhirat. Karena itu, kalau ditelusuri dalam konsep Islam, sesungguhnya yang menarik adalah bahwa surga bagi wanita lebih mudah dicapai dari pada kaum pria. Seperti dialog yang terjadi antara Asma' binti Sakan dengan Rasulullah saw. Asma' berkata, "Wahai Rasulullah, bukankah Engkau diutus oleh Allah untuk kaum pria dan juga wanita. Mengapa sejumlah syariat lebih berpihak kepada kaum pria? Mereka diwajibkan jihad, kami tidak. Malah, kami mengurus harta dan anak mereka di kala mereka sedang berjihad.

Berikut ini dipaparkan beberapa prinsip kesetaraan gender dalam Islam, sbb.: 1. Laki-Laki Dan Perempuan Sama-Sama Hamba Allah

Salah satu tujuan penciptaan manusia, untuk menyembah Allah SWT., sebagaimana dinyatakan dalam surat az-Zariyat/51:56, sbb. :

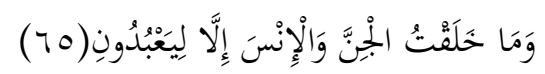

Dan Aku tidak menciptakan jin dan manusia melainkan supaya mereka menyembah-Ku.

Semua manusia mempunyai kesempatan sama untuk menjadi hamba ideal di mata Allah SW'T., yaitu menjadi orang yang bertaqwa. Untuk mencapai derajat ini tidak dikenal adanya perbedaan jenis kelamin maupun etnis. Dalam kapasitasnya sebagai hamba Allah, laki-laki dan perempuan akan mendapatkan penghargaan dari Tuhan sesuai kadar pengabdiannya, sebagaimana dinyatakan surat An-Nahl/16:97, sbb.:

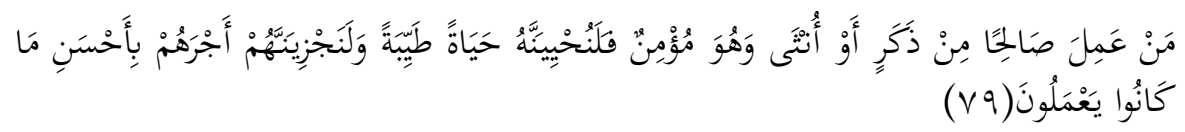

Barangsiapa yang mengerjakan amal saleh, baik. laki-laki maupun perempuan

\footnotetext{
${ }^{24}$ Nasaruddin Umar, "Memahami Bahasa Agama tentang Perempuan” dalam Mimbar Agama \& Budaya, Vol. XVIII, No. 2, 2001, hal. 111
} 
dalam keadaan beriman, maka sesunggubnya akan Kami berikan kepadanya kehidupan yang baik dan sesungguhnya akan Kami beri balasan kepada mereka dengan pabala yang lebih baik dari apa yang telah mereka kerjakan.

2. Laki-Laki Dan Perempuan Sebagai Khalifah Di Muka Bumi

Maksud dan tujuan penciptaan manusia di muka bumi di samping untuk menjadi hamba yang tunduk dan patuh serta mengabdi kepada Allah, juga untuk menjadi khalifah di bumi, sebagaimana dinyatakan dalam surat al-An'am/6:165, sbb.:

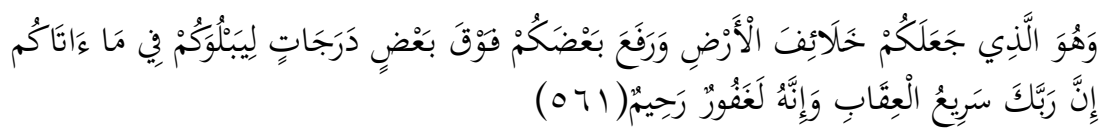

Dan Dialah yang menjadikan kamu penguasa-penguasa di bumi dan Dia meninggikan sebahagian kamu atas sebahagian (yang lain) beberapa derajat, untuk mengujimu tentang apa yang diberikan-Nya kepadamu. Sesunggubnya Tuhanmu amat cepat siksaan-Nya, dan sesunggubnya Dia Maha Pengampun lagi Maha Penyayang.

Kata khalifah dalam ayat Alquran surat al-An'am/6:165 ini tidak menunjuk pada salah satu jenis kelamin atau kelompok etnis tertentu.

3. Laki-Laki Dan Perempuan Menerima Perjanjian Allah

Laki-laki dan perempuan sama-sama mengemban amanah dan menerima perjanjian dari Tuhan. Sebelum anak manusia keluar dari rahim ibunya, terlebih dahulu harus menerima perjanjian dari Allah dan berikrar akan keberadaan-Nya sebagaimana dinyatakan dalam surat Al-A'raf/7:172, sbb.:

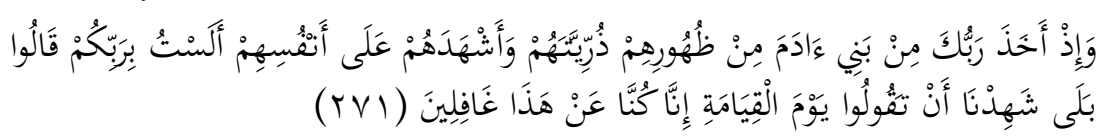

Dan (ingatlah), ketika Tuhanmu mengeluarkan keturunan anak-anak Adam dari sulbi mereka dan Allah mengambil kesaksian terhadap jiwa mereka (seraya berfirman): "Bukankah Aku ini Tubanmu?" Mereka menjawab: "Betul (Engkau Tuhan kami), kami menjadi saksi". (Kami lakukan yang demikian itu) agar di hari kiamat kamu tidak mengatakan: "Sesungguhnya kami (bani Adam) adalab orangorang yang lengah terhadap ini (keesaan Tuhan)"

Dengan demikian, sejak awal kejadian manusia, dalam Islam tidak dikenal sistem diskriminasi jenis kelamin. Laki-laki dan perempuan sama-sama menyatakan ikrar ketuhanan yang sama.

4. Laki-Laki Dan Perempuan Sama-Sama Berpotensi Meraih Prestasi

Peluang meraih prestasi maksimum dimiliki setiap laki-laki maupun perempuan tanpa ada pembedaan. Islam menawarkan konsep kesetaraan gender yang ideal dengan memberi ketegasan bahwa prestasi individual, baik dalam bidang spiritual maupun karier profesional tidak harus dimonopoli salah satu jenis kelamin, sebagaimana dinyatakan dalam surat Ali-Imran/3:195, sbb.:

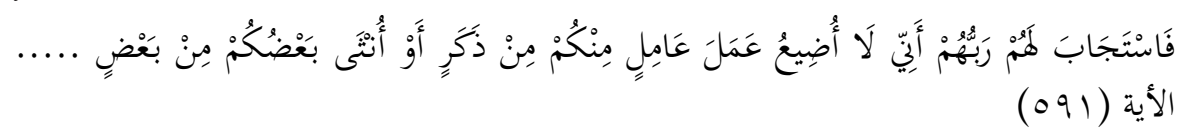

Maka Tuban mereka memperkenankan permohonannya (dengan berfirman), "Sesunggubnya Aku tidak menyia-nyiakan amal orang-orang yang beramal di antara 
kamu, baik laki-laki atau perempuan, (karena) sebagian kamu adalah turunan dari sebagian yang lain.

Namun dalam kenyataannya, di tengah-tengah masyarakat sekarang ini, konsep ideal tersebut masih membutuhkan tahapan dan sosialisasi karena terdapat beberapa kendala budaya yang tidak mudah diselesaikan ${ }^{[12]}$.

\section{Simpulan}

Meskipun Islam telah menawarkan kesetaran gender sebagaimana di kemukakan di atas, namun tidak dapat dipungkiri, realitas kehidupan sosial dewasa ini masih diwarnai ketimpangan gender. Pemikiran masyarakat masih banyak dipengaruhi dengan pemahaman keagamaan yang tidak adil secara gender, yang mereka anggap sebagai "agama" itu sendiri. Untuk mengatasi hal ini, tidak ada cara lain kecuali menggali dan menemukan kembali semangat keadilan, rahmatan lil alamin, anti kekerasan, dan anti diskriminasi dalam sumber-sumber agama yang otentik. Sebab agama Islam tidak mungkin bertentangan dengan kemanusiaan dan nilai-nilai universal; keadilan, kebajikan, dan kesetaraan.

Sungguhpun demikian kelompok Islam liberal bersifat kritis tentang posisi wanita dalam tradisi masyarakat Islam terutama konsep poligami dan hak pewarisan harta pusaka di mana anak perempuan menerima kurang dari anak lelaki. Mereka juga kritis dalam konsep wanita sebagai kepala negara dan wanita tidak seharusnya dipisahkan dari pria dalam masjid. Beberapa Muslim liberal setuju wanita menjadi imam dalam salat dengan makmum lelaki dan perempuan.

Beberapa Muslim feminis juga menolak kewajiban hijab, dengan mengklaim pakaian yang sopan adalah cukup untuk lelaki dan perempuan. Bagaimana pun beberapa Muslim feminis memakai hijab sebagai simbol menentang perlakuan wanita sebagai objek seks

\section{Daftar Pustaka}

Anjar Nugroho, Pikiran-Pikiran Liberal Anak Muda Mubammadiyah, (Yogyakarta: SM Press, 2005).

Albert Hourani, Arabic Thought in the Liberal Age (1798-1939), (London: Oxford University Press,1962).

Clifford Geertz, Islam Observed Religious Development in Marocco and Indonesia, (Chicago: University of Chicago Press, 1968)

Charles Kurzman,Wacana Islam Liberal, Pengantar Islam Dan Konteks Islaminya, (Jakarta, Paramadina, 2003).

Ernest Gelner, Moslem Society, (Cambrige: Cambridge University Press, 1981).

Eriyanto, Analisis Wacana, (Yogyakarta, LKiS, 2001).

http://www.isnet.media.com/nur kholis majid (jurnal pemikiran universitas paramadina, jakarta)

http://www.isnet.media.com/nur kholis majid (jurnal pemikiran Universitas Paramadina, Jakarta). 
Ira M. Lapidus, Sejarah Sosial Umat Islam, Bagian 3, terj. Ghufron A. Mas'adi (Jakarta: Raja Grafindo Persada, 1999).

John L. Esposito dan James P. Piscatori, "Islam dan Demokrasi”, dalam Jurnal Islamica, Jurnal Dialog Pemikiran Islam, No. 4 April-Juni 1994.

Julia Cleves Mosse, Gender \& Pembangunan, (Yogyakarta: Pustaka Pelajar, 1996).

Kosasih, Ahmad. HAM Dalam Perspektif Islam, (Jakarta:Salemba Diniyah, 2003).

Leila Ahmed, Wanita \& Gender Dalam Islam, (Jakarta: PT. Lentera Basritama, 2000).

Zuly Qodir, Islam Liberal, Paradigma Baru Wacana dan Aksi Islam Indonesia, (Yogyakarta, Pustaka Pelajar, 2003)

M. Syafi'i Anwar, "Negara dan Cendikiawan Muslim Indonesia Orde Baru”, dalam Saiful Muzani, (ed.), Pembangunan dan Kebangkitan Islam di Asia Tenggara, (Jakarta: LP3ES, 1993).

M. Jandra, "Pluralisme Baru dan Cinta Kebangsaan", Amin Abdullah, dkk, Tafsir Baru Studi Islam dalam Era Multi Kultural (Yogyakarta: Kurnia Kalam Semesta, 2002).

Mansour Fakih, Analisi Gender \& Transformasi Sosial, (Yogyakarta: Pustaka Pelajar, 1996).

Nasaruddin Umar, "Memahami Bahasa Agama tentang Perempuan” dalam Mimbar Agama \& Budaya, Vol. XVIII, No. 2, 2001.

Pius A. Partanto dan M. Dahlan Al Barry, Kamus Ilmiah Populer (Surabaya: Ar Kolah, 1994).

Sukron Kamil, Islam dan Demokrasi: Telaab Konseptual dan Historis (Jakarta: Gaya Media Pratama, 2002).

Yamani, Antara Al-Farabi dan Khomeini: Filsafat Politik Islam (Bandung: Mizan), 2002.

Zahara D. Noer, "Kemitrasejajaran Pria dan Wanita dalam Perspektif Islam", dalam Tuntunan Islam tentang Kemitrasejajaran Pria dan Wanita, (Jakarta: Majlis Ulama Indonesia, 1999). 